\title{
HK People Must Understand They've Become a Pawn
}

\begin{abstract}
While the protests in Hong Kong are widely seen as a fight for democracy and freedom, they must also be understood in the context of the growing US-China geopolitical contest.
\end{abstract}

\section{Editor's Note}

Why have the US and China, the world's two biggest powers, increasingly turned hostile against each other? How should Hong Kong affairs be understood in the context of China-US rivalry? The US and other Western countries are in a deep internal crisis. Is it time for them to reform their political systems? In a world of profound change, international affairs observers nowadays are working to find answers to these questions. Global Times reporters Yu Jincui and Bai Yunyi solicited the insights of Kishore Mahbubani, distinguished fellow at the Asia Research Institute, National University of Singapore, and a veteran diplomat, in a written interview recently.

GT: Does the deterioration in China-US relations in recent months go beyond your expectation? Will this trend continue after the US November election? How will different election results influence bilateral relations?

Mahbubani: The recent deterioration of China-US relations was not a surprise. It could have been predicted. As I argue in my book, Has China Won?, the US decision to launch a geopolitical contest against China was driven by a few major structural forces. Here are a few. Firstly, as Harvard Professor Graham Allison has observed, such a geopolitical contest inevitably breaks out when the No. 2 power (today China) becomes stronger relative to the No.1 power (today the US). Secondly, the US resents the growing international influence of China, through initiatives like AIIB and the Belt and Road Initiative. Thirdly, as former assistant secretary of state Kurt Campbell has documented, Washington expected that "US power and hegemony could readily mold China to United States' liking." In short, the US expected China to become

Originally published in Global Times, Jun 18, 2020 
like the US, a liberal democracy. The US is disappointed that this expectation (even if misplaced) didn't happen. In addition, the Western psyche has long had a fear of the "yellow peril." As a result of such structural forces, there is bipartisan support in the US for the current US policy of launching a contest against China.

This US-China geopolitical contest will continue after November, regardless of who wins. Nonetheless, there is also no doubt that a Biden administration (if it emerges) will be more courteous toward China. The public insults will cease. Despite this, the US could also become a formidable competitor for China under Biden as his administration will be able to rally more effectively the friends and allies of the US, like the Europeans, who have become disenchanted with the Trump administration. Nonetheless, there is also greater hope that a more rational Biden administration could accept my book's recommendation that the US and China should work together, instead of against each other, to handle common challenges, like Covid-19 and global warming.

\section{GT: China and the US have seen increasing competition and conflicts in terms of economy, technology, political systems, and global leadership. In which areas do you think the conflicts can be alleviated and in which areas are conflicts likely to intensify?}

Mahbubani: It is difficult to anticipate the future course of the US-China geopolitical contest because the US has not worked out a comprehensive and thoughtful longterm strategy for managing China. It was Dr. Henry Kissinger who shared this insight with me. As a result of a lack of strategy, many of the actions taken by the US against China, like the trade war, are also hurting the interests of the American people, especially after Covid-19.

The fundamental question that the US needs to answer before formulating a strategy on China is whether the key strategic goal of the US should be to protect the primacy of the US in the global system or to enhance the well-being of the people. The choice is clear: primacy or people.

So far, many in the administration believe that the US should protect its primacy. Sadly, this impulse has also resulted in the US fighting unnecessary wars, wasting, for example, US\$ 5 trillion in unnecessary post-9/11 wars. However, the average income of Americans in the bottom 50\% has gone down over the past 30 years. If this US\$ 5 trillion had been given instead to the bottom 50\%, each American in this group would have received a check for US\$30,000.

In short, if the US focuses its efforts on improving the well-being of its people and dealing with climate change, many areas of competition can be avoided, like the trade wars. However, if the US focuses on primacy, the US competition with China will step up in many areas, resulting in many actions like blocking Huawei from selling its 5G technology and resisting Chinese initiatives, like the Belt and Road Initiative.

The world hopes that the US will take the wiser course of enhancing the well-being of its people. 
GT: Some scholars in China and the US think that China-US relations have been at their worst point over the past four decades and that it will take decades to resolve the estrangement. If this is the case, how will the China-US confrontation influence world patterns in the next few decades? Will countries have to take sides?

Mahbubani: There are 330 million people living in the US and 1.4 billion in China. Six billion people live outside these two countries. It is clear that these six billion people, who live in 191 countries, are deeply troubled by the US-China geopolitical contest as they believe both countries should come together with the rest of the world to deal with pressing global challenges, like Covid-19 and global warming. Hence, few countries, if any, are rushing to take sides. The vast majority of humanity would be relieved and happy if both US and China could set aside their geopolitical contest and focus on restarting the global economy, which has deeply stalled since Covid-19, and retooling it to address climate change. One of the key goals of my book, Has China Won?, is to persuade both countries to pay greater attention to the views of the rest of the world.

One clear indication of the views of the rest of the world was provided by the refusal of any country to follow the US when it left the World Health Organization (WHO). Hence, one way to send signals of the views of the 7.8 billion of our world is to revitalize and work with key multilateral organizations, like the UN. Both Chancellor Angela Merkel and President Emmanuel Macron have spoken out about the importance of multilateralism. The world should encourage the European Union to provide leadership in revitalizing multilateral institutions. They could help to stabilize a world disrupted by the US-China geopolitical contest.

\section{GT: You recently said Hong Kong has become a "pawn" in the escalating rivalry between the US and China, can you elaborate on your views?}

Mahbubani: In the geopolitical contest that the US has launched against China, the US will naturally look for opportunities to embarrass China. This is natural superpower behavior. The US also believes that both the recent unrest in Hong Kong and the proposed enactment of a national security law provide a convenient propaganda weapon to use against China, especially in the Western world. It's therefore important for the people of Hong Kong to realize that it has become a political football that will be kicked around in the geopolitical contest. In any football match, the players enjoy kicking the ball and using it to score goals, especially propaganda goals. Sadly, the football gets damaged. If the people of Hong Kong do not understand that they have become a pawn in a geopolitical contest, they may come to grief.

Many of the Western countries who have been supporting the demonstrations and disruptions in Hong Kong believe that their interests are best served by instability in Hong Kong as it is seen as an embarrassment for China. Actually, if the Western countries, including the US and the UK, did a sober calculation of their real longterm interests, especially their primary interest in revitalizing the global economy, they would come to the realization that stability in Hong Kong and its continuation 
as a vibrant commercial and financial center could enable Western companies to get full benefit from China's growth.

GT: Hong Kong under the British colonial rule was one of the frontlines of the West in Asia before 1997, but now China has resumed sovereignty over Hong Kong. Beijing is enacting a national security law for the city but is strongly opposed by the West. What's behind such a clash?

Mahbubani: Every country has national security laws. Article 23 of the Basic Law states explicitly that, "The Hong Kong Special Administrative Region shall enact laws on its own to prohibit any act of treason, secession, sedition, subversion against the Central People's Government, or theft of state secrets, to prohibit foreign political organizations or bodies from conducting political activities in the Region, and to prohibit political organizations or bodies of the Region from establishing ties with foreign political organizations or bodies." This failure of the Hong Kong authorities to exercise their responsibilities has led to the central government enacting such legislation.

Every country has national security laws. These laws are designed to protect countries from foreign interference in their societies, especially in their domestic politics. For example, the US has the freest press in the world but, until recently, no foreigner could own a TV station in the US. Rupert Murdoch had to give up his Australian citizenship and become a US citizen before he could own a TV station in the US. From 2017 onwards, the US has allowed 100\% foreign ownership. Nonetheless, the State Department has used alternative legislation, the Foreign Agents Registration Act (FARA), to regulate foreign-owned TV stations. The American people were outraged when reports surfaced that Russian money may have helped the election of Trump, even though these reports were not confirmed. Curiously, as the New York Times has documented, the US has a history of intervening in other countries' elections. Dov Levin, assistant professor of International Relations at Carnegie Mellon University, found 81 instances of overt and covert interventions in other countries' elections by the US, as compared to 36 by the Soviet Union/ Russia, between 1946 and 2000. On 17 February 2018, Scott Shane wrote in the New York Times, "The United States' departure from democratic ideals sometimes went much further. The C.I.A. helped overthrow elected leaders in Iran and Guatemala in the 1950s and backed violent coups in several other countries in the 1960s. It plotted assassinations and supported brutal anti-Communist governments in Latin America, Africa and Asia."

Since every country in the world has national security laws, the new laws to be adopted in Hong Kong can follow best international practices in countries that have civil and personal rights comparable to Hong Kong's. There is no need to reinvent the wheel here.

I am confident that Hong Kong can remain a vibrant commercial and financial hub and an open cosmopolitan city if the national security legislation conforms to well-established international norms and is implemented by the independent courts of Hong Kong. However, to achieve this goal, the leaders of Hong Kong must make 
a massive effort in public education to explain these new laws to the people of Hong Kong.

GT: The death of George Floyd has led to massive protests in the US. Not long after the protests began, US politicians have threatened to use the army to quell protests. Why did they take a totally different attitude toward Hong Kong's violent protesters?

Mahbubani: In most societies (but not all), peaceful protests are legal. In no society are violent demonstrations legal. Hence, it was legitimate for both the Hong Kong police and US police officers to clamp down on violent demonstrations, although wise police forces do it with careful restraint. The Hong Kong Police have done a truly admirable job as they have been able to respond effectively to violent demonstrations without any loss of life. By contrast, some American citizens have lost their lives.

It was a huge mistake for some Hong Kong demonstrators to turn violent. In all healthy societies, there is one cardinal unbreakable rule. The state authorities must have a monopoly on violent methods to preserve law and order. This is why police officers have the authority to legally arrest citizens. Citizens don't have the authority to arrest police officers. The violent demonstrators have done enormous damage to their cause by using stones and metal rods as weapons to attack policemen in Hong Kong.

History teaches us that the most successful demonstrations have been peaceful ones. Great leaders, like Mahatma Gandhi and Martin Luther King have led peaceful protests. At the same time, most protests arise out of underlying socio-economic conditions. It is a tragedy that the living standards of the bottom 50\% in Hong Kong, like the bottom $50 \%$ in the US, have not gone up in recent times. This is the root cause of the demonstrations in Hong Kong and the US. Fortunately, Hong Kong is in a good position to take care of its bottom $50 \%$. Hence, I remain optimistic for Hong Kong.

GT: The US response to the Covid-19 pandemic is disappointing. Why has the world's only superpower performed so poorly amid the epidemic? Is the Trump administration to blame or is it a result of the accumulated problems in US society and its political system?

Mahbubani: The US response to Covid-19 is particularly surprising and disappointing because for many decades American society was the source of envy and inspiration for the world. When Mr. Deng Xiaoping made his famous visit to the US in January-February 1979, the Chinese people could see how well off the American working classes were then. Sadly, since then, as I document in Has China Won?, the The US has become the only major developed society where the average income of the bottom 50\% decreased over the 30-year period to 2010. Two Princeton University economists, Anne Case and Angus Deaton, have documented how this has led to a "sea of despair" among working class white people. They also document how poor economic prospects "compounds over time through family dysfunction, social isolation, addiction, obesity, and other pathologies". 
It is therefore a mistake to only blame the Trump administration for the current problems in American society. They have been accumulating over time. The major contributor to the problems of American society was the Reagan-Thatcher revolution. President Ronald Reagan famously said, "Government is not the solution to our problem, government is the problem." As a result, key government institutions, including internationally respected expert bodies like the FAA and FDA, have been seriously weakened. When institutions of government weaken, the ability of the government to handle social crises, like inequality in the US or health crises, like Covid-19, is also severely hampered.

\section{GT: In your opinion, after the Covid-19 pandemic, will the West gradually begin an era of "big government?" Since the eighteenth century, the West has barely reformed its political system. Do they need to make a reflection or reforms?}

Mahbubani: In speaking about the "West" and "big government," one has to make a major distinction between the European Union (EU) member states and the US. It's true that both the EU members and the US performed badly in response to Covid-19 as their fatality rates per million (Spain 580, Italy 562, UK 610, USA 339) are higher than East Asian rates (for example, Japan 7, China 3, Singapore 4 and Vietnam 0).

Yet, on balance, many EU member states have developed a healthy balance between the roles of government and markets in developed societies. Their experience mirrors the wise advice of the Nobel Laureate Amartya Sen who said that the countries who succeed are those who combine the "invisible hand" of free markets and "visible hand" of good governance. This is why some of the Scandinavian states, like Denmark and Finland, are viewed as models for the rest of the world to follow.

By contrast, after President Ronald Reagan, the US has abandoned the "visible hand" of good governance. The US needs to develop a new consensus on rebuilding key government institutions to take care of the significant socio-economic problems that the US has built up. William J. Burns, the president of Carnegie Endowment for International Peace and a former deputy secretary of state has written that he watched "the slow and painful desiccation of government - political leaders far more interested in demeaning institutions than modernizing them, bureaucracies sinking beneath too many layers and procedures, and a public that saw a yawning gap between its interests and those of policy elites." He further stated, "First, it is long past time to end the war on government." If the American people were to heed the advice of Ambassador William Burns and end their war on government, they would be better off.

GT: The unrest in the US is worrying. Will it trigger similar disorder or chaos in more countries? Will the world see more collapses of governments, widening wealth gaps, and turmoil in more countries in the post-pandemic era?

Mahbubani: The US remains the world's largest economy. If its growth falters, or if it continues to slide backward, this will be bad for the world, not just for the US. It is in the interest of the global community to see the US economy grow again.

However, if the US economy, as well as the economies of the rest of the world, are to grow again, we must go back to the global consensus that existed in the 
world before President Trump was elected. Firstly, we must agree that the world is better off when we refrain from trade wars and instead work together to lower tariff and non-tariff barriers to trade. Second, we must work to strengthen, rather than weaken, the World Trade Organization. Indeed, as I explain in my book, The Great Convergence (which has been translated into Chinese), we must strengthen all UN affiliated multilateral organizations, including the World Health Organization. Third, we must also continue to push for Free Trade Agreements like the RCEP (Regional Comprehensive Economic Partnership) and the CPTPP (Comprehensive and Progressive Agreement for Trans-Pacific Partnership). It's truly encouraging that Premier Li Keqiang said on May 28, 2020, "China has a positive and open attitude toward joining the CPTPP".

In short, even though the economic slowdown in the US will be a drag on the global economy, it is still possible for East Asia, including both Northeast Asia and Southeast Asia, to keep growing if we retain our faith in open economies and free trade. Just as the US and Europe were able to keep their economies growing strongly in the 1950s and 1960s by progressively liberalizing their economies more and more, today East Asia can set the pace. As a result, many of the developing economies in the rest of Asia, Africa and Latin America will be drawn to integrate their economies more closely with East Asia.

It's fortunate that the 1945 rules-based order, gifted by the West to the world, has not collapsed, even though the Trump administration has walked away from it. Even though many Europeans feel as insecure about the future as many Americans do, Europe, led by Germany and France, have not walked away from global multilateral institutions. Using the platform of the Asia-Europe Meeting (ASEM), pioneered by former Singapore Prime Minister Mr Goh Chok Tong, East Asia and Europe should work together to stabilize the global rules-based order.

\footnotetext{
Open Access This chapter is licensed under the terms of the Creative Commons AttributionNonCommercial-NoDerivatives 4.0 International License (http://creativecommons.org/licenses/bync-nd/4.0/), which permits any noncommercial use, sharing, distribution and reproduction in any medium or format, as long as you give appropriate credit to the original author(s) and the source, provide a link to the Creative Commons license and indicate if you modified the licensed material. You do not have permission under this license to share adapted material derived from this chapter or parts of it.

The images or other third party material in this chapter are included in the chapter's Creative Commons license, unless indicated otherwise in a credit line to the material. If material is not included in the chapter's Creative Commons license and your intended use is not permitted by statutory regulation or exceeds the permitted use, you will need to obtain permission directly from the copyright holder.
}

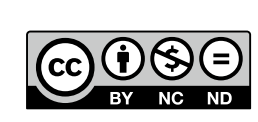

